\title{
Lektier Online - didaktisk design af et uformelt online læringsrum?
}

\section{Nina Bonderup Dohn}

Lektor, ph.d.

Institut for Design og Kommunikation, Syddansk

Universitet

\section{Hanne Skipper Degnebolig}

Cand. it. i Kommunikation og Organisation Underviser hos Sprogcenter Midt

\section{Pernille Holm Lindhardt}

Cand.mag., gymnasielærer

Projektkoordinator, Lektier Online

\section{Kirsten Lund}

Formidlingschef

Naturhistorisk Museum i Aarhus
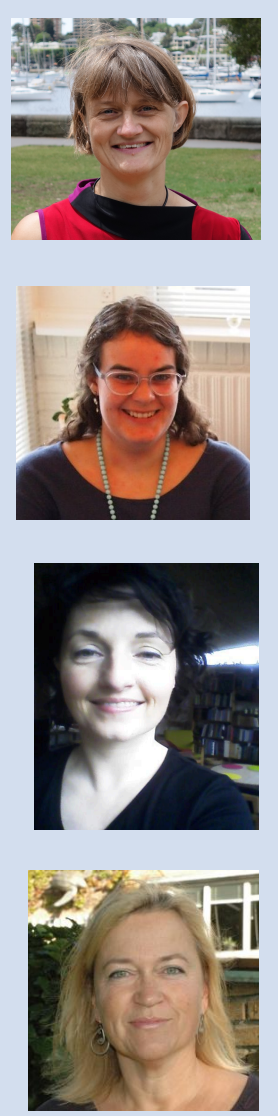


\section{Abstract}

Lektiehjælpsmuligheder for elever i grundskolen og på ungdomsuddannelser er i stigende grad kommet på den politiske og samfundsmæssige dagsorden. I denne artikel undersøger vi det didaktiske design i Lektier Online; et lektiehjælpstilbud for folkeskole- og ungdomsuddannelseselever baseret på frivillige universitetsstuderende som lektiehjælpere. Lektier Online adskiller sig fra sig fra andre tilbud i offentligt regi ved at finde sted på en online platform, hvor elev og lektiehjælper er anonyme for hinanden. Vi identificerer fire betydninger af 'didaktisk design', som alle behandles for Lektier Online. Vi opstiller en hypotese om Lektier Online-konceptet som frembydende et forholdsvis uformelt læringsrum samt tre eksplorative forskningsspørgsmål, der adresserer brugen af Lektier Online-platformens forskellige medier, deres virkemåde i læringskommunikationen mellem lektiehjælper og elev, samt muligheder for at kvalificere denne læringskommunikation didaktisk. Hypotese og forskningsspørgsmål undersøges gennem et eksplorativt observationsstudie af Lektier Onlines ungdomsuddannelsesdel, og lektiehjælpssessionerne analyseres vha. positionerings- og affordanceteori. Vi konkluderer, at lektiehjælper og elev i samarbejde forhandler læringskommunikationen med anknytning til et lærer-elev narrativ og peger på, hvordan de primære kommunikationsmedier, tale og chat, samt de primære arbejdsmedier, digital tavle og Google Docs, bidrager i denne forhandling.

\section{English abstract}

The development of homework tutoring options for students in primary and secondary education is accorded increasing political and societal attention. In this article we investigate the pedagogical design of Lektier Online; a homework tutoring option for students in primary and secondary education, based on voluntary tutoring by university students. Lektier Online differs from other public homework tutoring options by taking place on an online platform where students and tutors are anonymous to each other. We identify four senses of 'pedagogical design' and look at each of them for Lektier Online. We formulate the hypothesis that Lektier Online constitutes a relatively informal learning space and articulate three explorative research questions concerning the use of the different media on Lektier Online's platform, their functioning in the learning communication between tutor and student, and ways to enhance this learning communication pedagogically. Hypothesis and research questions are investigated through an explorative observational study of Lektier Online's upper secondary education part and homework tutoring sessions are analyzed with positioning theory and affordance theory. We conclude that tutor and student cooperate in negotiating the learning communication in correlation to a teacher-student narrative and we point out the contribution to this negotiation of the primary communication media, talk 
and chat, as well as the primary work media, digital whiteboard and Google Docs.

\section{Indledning}

Igennem de senere år er der i stigende grad blevet sat politisk og samfundsmæssigt fokus på udvikling af lektiehjælpsmuligheder for elever i grundskolen og på ungdomsuddannelser. På grundskoleniveau har alle folkeskoler fra skoleåret 2015-16 haft obligatorisk lektiecafe som integreret del af skoledagen, og lektiehjælpstilbud på skolen er ligeledes udbredt på ungdomsuddannelserne. Også på flere folkebiblioteker er der etableret lektiehjælpsordninger, ligesom en række private firmaer tilbyder "mentorordninger" mod betaling. En grundlæggende ide bag alle tilbud i offentligt regi er, at de kan være med til at modvirke forskelle i socioøkonomiske vilkår for eleverne (populært: bryde den sociale arv): I udgangspunktet står elever af forældre uden videregående uddannelse svagere i kraft af forældrenes manglende faglige forudsætninger for at hjælpe dem med deres lektier. Tanken er, at sådanne elever i stedet skal kunne hente den fornødne hjælp i lektiehjælpstilbuddene. Der er selvsagt ikke samme vision bag private tilbud.

I denne artikel sætter vi fokus på et særligt lektiehjælpstilbud i offentligt regi, nemlig Lektier Online; der er udviklet og ejet af Statsbiblioteket. I Lektier Online tilbyder frivillige universitetsstuderende gratis én-til-én lektiehjælp til elever i folkeskolen og på ungdomsuddannelser via en online platform hosted af Statsbiblioteket. Ud over at foregå gennem et online medie adskiller Lektier Online sig umiddelbart fra andre lektiehjælpstilbud ved, at elever og lektiehjælpere er anonyme for hinanden. Det empiriske studium, der ligger til grund for artiklen, angik udelukkende ungdomsuddannelsesdelen.

Mere specifikt undersøger vi i denne artikel det didaktiske design i Lektier Online. Vi forstår begrebet 'didaktisk design' bredt som "formgivning af muligheder for at lære", hvor dét, der formgives, kan være såvel artefakter og rum som aktiviteter, forløb og generelt måder at tage artefakter og rum i brug på (Dohn \& Hansen, 2016; Dohn et al., 2016). I de angivne tekster identificeres en række betydninger af begrebet 'didaktisk design'. Med afsæt i disse og konkretiseret til nærværende sammenhæng, kan Lektier Online siges at involvere didaktisk design i følgende betydninger:

A. Konceptet bag den virtuelle lektiehjælp: at frivillige universitetsstuderende, samlet i fysiske call-centre, yder online hjælp til elever på lavere uddannelsestrin, først og fremmest inden for deres studieområde - didaktisk design i betydningen 'didaktisk organiseringsprincip'

B. Den online platform med de forskellige medier, den integrerer, og den læringskommunikation, den derigennem muliggør og understøtter - 
didaktisk design i betydningen 'didaktisk tilrettelagte

læringsressourcer/-miljø’

C. De didaktiske modeller og principper, som lektiehjælpen planlægges udført ud fra - didaktisk design i betydningen 'didaktisk planlægning og tilrettelæggelse'

D. Den måde, lektiehjælpen udføres på i praksis - didaktisk design i betydningen 'de implicitte didaktiske principper, som udførelsen udtrykker'

Vi ser på det didaktiske design i Lektier Online i alle fire betydninger. Vi redegør først for konceptet bag den virtuelle lektiehjælp (betydning A). På den baggrund formuleres en hypotese og tre eksplorative forskningsspørgsmål til undersøgelse af den måde, lektiehjælpen faktisk udføres på i praksis (betydning D), af de kommunikations- og læringsmuligheder, som den online platform frembyder (betydning B) samt af implikationerne for, hvordan lektiehjælpen burde tilrettelægges (betydning C). I vores analyse trækker vi på positioneringsteori (Harré \& van Langenhove, 1999) og affordanceteori (Dohn, 2009; Gibson, 1986), med udgangspunkt i en grundlæggende situeret tilgang til etablering af læringsmuligheder i konkrete situationer (Greeno, 2011; Greeno \& Gresalfi, 2008). Vi forstår begrebet 'læringskommunikation' forholdsvis uprætentiøst, som 'kommunikation, der sigter mod læring', hvor 'sigtet' godt kan være sat af situationen (som når en elev søger hjælp til en opgave), og hvor det ikke er givet, at resultatet faktisk er læring. Når elever og lektiehjælpere kommunikerer om en opgave, er det således pr. definition 'læringskommunikation', uanset om eleven faktisk lærer noget af kommunikationen eller ej.

Vores artikel supplerer en anden artikel, der netop er blevet bragt i Læring og Medier (Hansen \& Remvig, 2016). Heri rapporterer Hansen og Remvig fra et pædagogisk designforskningsprojekt, hvis mål var udvikling af en vejledningsdidaktik for lektiehjælperne i Lektier Online (didaktisk design i betydning C). Vores undersøgelse pågik samtidig med Hansens og Remvigs projekt. De lektiehjælpere, der indgik i vores undersøgelse, havde således ikke gennemgået det reviderede kursus, der var et udkomme af deres projekt.

\section{Præsentation af konceptet i Lektier Online}

Det grundlæggende koncept (didaktisk design i betydning A) i Lektier Online er, at personer, der selv er under uddannelse, dvs. er 'lidt længere fremme i systemet', yder lektiehjælp inden for deres fag til børn og unge, der er 'knapt så langt'. Målet er at skabe et tilbud om fri adgang til lektiehjælp af høj faglig og didaktisk kvalitet i et trygt læringsrum. Projektet henvender sig både til de elever, der kæmper med det faglige, og de fagligt stærkere elever, der har brug for sparring og inspiration. Intentionen er at give hjælp til selvhjælp og styrke elevernes faglige selvtillid og mod på læring. 
Lektier Online har eksisteret siden 2010, hvor projektet med afsæt i bibliotekernes fysiske lektiecafeer blev lanceret på grundskoleniveau for at kunne tilbyde lektiehjælp til børn og unge fra udsatte boligområder med særligt fokus på at nå ud til de tosprogede drenge, som ikke benyttede fysiske lektiecafeer. Målet var at løfte det faglige niveau hos målgruppen i grundskolen med henblik på at få flere unge igennem en ungdomsuddannelse. Lektier Online er i dag tilgængeligt for alle folkeskoleelever med Unilogin fra deres skole. Dette finansieres af Satspuljemidler. Interesserede ungdomsuddannelser kan tegne et abonnement på Lektier Online og dermed tilbyde lektiehjælpen til alle deres elever. A.P. Møller Fonden støtter ungdomsuddannelsesprojektet.

Projektet er organiseret omkring fire callcentre i universitetsbyerne Aarhus, Aalborg, Odense og København. Der er indgået partnerskaber med Aalborg Universitetsbibliotek (AUB), Syddansk Universitetsbibliotek/Odense Centralbibliotek (OCB) og Det Kongelige Bibliotek (KB), som sørger for lokaler og lektiehjælpere.

Lektiehjælpen udføres af frivillige universitetsstuderende, som rekrutteres lokalt i de relevante studiemiljøer til at give lektiehjælp i deres fag 2-3 gange om måneden. De gennemgår et obligatorisk kursus, hvor de introduceres til online kommunikation, online didaktik og lektiehjælp samt til selve ITplatformen. Herefter indgår de i Lektier Onlines frivilligstab. De tilbydes løbende kompetencekurser, sociale arrangementer og mulighed for at præge projektet gennem lokale lektiehjælperudvalg og -teams. Lektier Online opslår endvidere lønnede studiejobs, hvor erfarne lektiehjælpere varetager funktionen som vagtansvarlige (flyvere) i deres lokale callcenter. Flyvernes primære opgave er at sikre, at lektiehjælper-vagten i callcenteret og kommunikationen med eleverne fungerer hensigtsmæssigt.

Eleverne logger på lektiehjælpen i åbningstiden og stiller sig i kø til et bestemt fag. De har mulighed for at skrive, hvilket fagligt problem de gerne vil have hjælp til. Når det er elevens tur, går denne i én-til-én session med lektiehjælperen. De tilgængelige medier er webcam, lyd, chat, digital tavle, tegne- og skriveredskaber samt mulighed for at uploade billeder til tavlen. Lektiehjælper og elev kan desuden dele dokumenter via GoogleDocs. Eleven er anonym i lektierummet og vælger selv, om der bruges webcam, lyd og/eller chat. Eleverne kan få hjælp til deres faglige spørgsmål i 30-45 min.

Lektier Online (GYM), som vi her fokuserer på, er åbent søndag-onsdag kl. 1821 og tilbyder hjælp til dansk, engelsk, matematik, fysik, kemi - og en åben kategori, der hedder "andre fag". Lektiehjælperne vælger typisk at give lektiehjælp i et eller to af de primære fag. Har de desuden f.eks. spansk eller biologi i deres fagprofil, kan de vælge at hjælpe elever, der søger dette under "andre fag". 


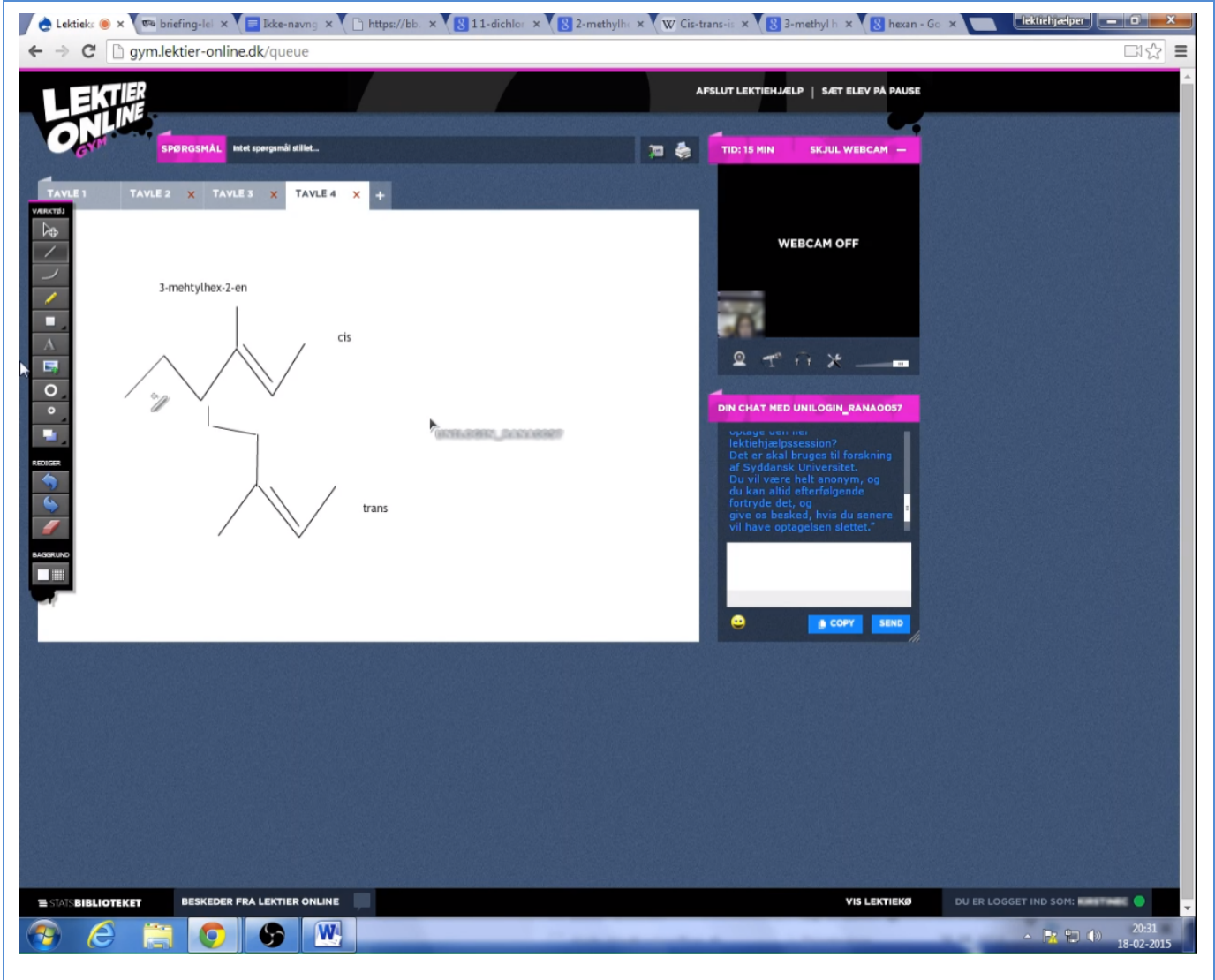

Figur 1. Brugergrænsefladen på Lektier Onlines platform.

Der er udviklet uddannelsesmaterialer, værktøjer, didaktik-modeller og workshops til de frivillige lektiehjælpere, der understøtter dem i at organisere de faglige sessioner med hensyntagen til den særlige udfordring, det er at give en-til-en lektiehjælp via en online platform. Men lektiehjælperne er ikke og forventes ikke at være professionelle undervisere. De er en faglig ressource, og gennem deres lektiehjælp opnår de praktisk erfaring med at formidle deres fag og lærer at kommunikere med elever om faglige spørgsmål.

\section{Undersøgelsesdesign}

Lektier Online baserer sig på, at lektiehjælper og elev begge er lærende i et samlet uddannelsessystem. Det gør det nærliggende at tænke på lektiehjælpen som en faglig støtte givet fra den mere erfarne til den mindre erfarne, hvor de i afgørende forstand er ligestillede (peers). I tråd hermed identificerer Hansen og Remvig det som en del af "lektievejledernes logik", at lektiehjælperne ser sig som "ikke-eksperten, den hjælpende storebror" (Hansen \& Remvig, 2016, p. 15, Model 3). At lektiehjælpen finder sted på en virtuel platform, der tilgås af eleven hjemmefra, uden læreradgang, rimeliggør samtidig den antagelse, a) at det etablerede læringsrum er forholdsvis uformelt i betydningen ikke undervisningsbaseret, og b) at det kan fungere som koblingspunkt mellem læringskontekster i hjem og skole. Elevudsagn om, at det er en fordel, at de 
kan "sidde hjemme i vante omgivelser, hvor de kan forberede sig lidt bedre på spørgsmålene"i, understøtter denne antagelse.

- Hypotese: Det didaktiske design (betydning A) knyttet til Lektier Online frembyder et forholdsvis uformelt læringsrum, der bygger bro mellem skolens formelle læringskontekst og hjemmets uformelle lektielæsningskontekst. Vejledningen i læringsrummet har form af faglig støtte fra en mere erfaren peer.

Til undersøgelse af denne hypotese samt til udforskning af Lektier Onlines didaktiske design i de tre andre betydninger, formulerede vi følgende tre eksplorative forskningsspørgsmål:

1. Hvordan anvendes de forskellige medier?

2. Hvordan fungerer de anvendte medier i læringskommunikationen mellem lektiehjælper og elev?

3. Hvilke didaktiske implikationer til kvalificering af Lektier Onlines didaktiske design har be-/afkræftelsen af hypotesen og afdækningen af medieanvendelsen til læringskommunikation?

Første og andet spørgsmål adresserer det didaktiske design i den online platform (betydning B), og den måde, læringskommunikationen faktisk udspiller sig på, hvilket muliggør en analyse af den implicitte didaktik i lektiehjælpssituationen (didaktisk design i betydning D). Tredje spørgsmål adresserer kvalificering af de principper, lektiehjælpen planlægges ud fra (didaktisk design i betydning C) med afsæt i den empiriske undersøgelse af hypotesen og forskningsspørgsmål 1 og 2 .

Undersøgelsesdesignet er således overordnet set et eksplorativt studie af den medierede læringskommunikation mellem lektiehjælper og elev i Lektier Onlines ungdomsuddannelsesdel. Det er foretaget af to forskere (1. og 2. forfatter) og to ansatte på Lektier Online (3. og 4. forfatter). Det er metodisk realiseret gennem observation på Statsbibliotekets callcenter, optagelse af lektiehjælpsessioner og efterfølgende analyse af disse sessioner. Vi foretog observation 5 aftener i perioden december 2014-april 2015. De første fire aftener var begge forskere til stede og mindst en af de ansatte. Den sidste aften var kun en ansat til stede. Formålet med observationen den første aften var at gøre forskerne bekendt med Lektier Online i praksis. Der blev ikke optaget sessioner. De øvrige 4 aftener (fordelt over $2 \frac{1}{2} 2$ måned) optog vi samtlige sessioner inden for ungdomsuddannelsesdelen, hvor lektiehjælper og elev begge indvilligede heri. Dette gav tilsammen 20 sessioner, hvoraf 2 af tekniske grunde er udgået fra analysen. De resterende 18 sessioner fordelte sig med $9 \mathrm{i}$ matematik, 3 i kemi, 1 i fysik, 3 i dansk, 1 i engelsk og 1 i samfundsfag. Forskerne observerede de konkrete sessioner, der blev optaget, undtagen når for mange sessioner blev optaget på én gang, og de derfor ikke kunne være til 
stede ved alle. Efter endt optagelse interviewede den observerende forsker kort lektiehjælperen om oplevelsen af sessionen.

De optagne sessioner blev efterfølgende set igennem og givet en indledende kategorisering ud fra de anvendte medier, fag, opgave, aktivitetsniveau for lektiehjælper og elev samt den overordnede kommunikative stemning. Dette første gennemsyn tydeliggjorde to primære medier for kommunikation om opgaven (herefter kommunikationsmedie), nemlig a) tale med lyd (evt. suppleret med billede) og b) chat, og to primære medier for arbejdet med løsningen af opgaven (herefter arbejdsmedie), nemlig c) den digitale tavle, og d) GoogleDocs.

Der er herefter foretaget en informationsorienteret udvælgelse (Flyvbjerg, 2006) af sessioner til nærmere analyse. Kriterierne for udvælgelse er formuleret ud fra forskningsspørgsmål 1 og 2 samt fordringen om at undersøge holdbarheden af artiklens hypotese. Til undersøgelse af forskningsspørgsmål 1 var udvalgskriterierne således:

- Alle fire kombinationer af primære kommunikations- og primære arbejdsmedier skal være repræsenteret

- Øvrige anvendte medier (mail, kamera, opslagsværker/lærebøger, søgning på internettet) skal alle være repræsenterede mindst 1 gang.

Til undersøgelsen af, om Lektier Online udgør et forholdsvis uformelt læringsrum, og hvordan læringskommunikationen udspiller sig med de anvendte medier, inddrog vi positioneringsteori og dens videreudvikling i en situeret tilgang til læringsmuligheder. I næste afsnit præsenterer vi dette teoretiske analyseblik, hvilket tillader os til slut i afsnittet at eksplicitere udvalgskriterierne for undersøgelsen af hypotesen og forskningsspørgsmål 2 .

\section{Teoretisk analyseblik og eksplicitering af udvalgskriterier}

Positioneringsteori (Harré \& van Langenhove, 1999) er en form for diskursanalyse, hvor hovedfokus er på den rolle, som kulturelle narrativer spiller i det, som mennesker siger og gør i konkrete situationer. Tilgangen tillader et blik på magtforhold i en kommunikationssituation, hvor dette blik er indlejret i en bredere spørgen til kulturelt medierede forståelsesrammer og personers indplacering i disse. Den egner sig godt som analyseblik til undersøgelsen af vores hypotese: Potentielt kan kommunikationen mellem lektiehjælper og elev tænkes at knytte an til kulturelle narrativer hidrørende mere formelle læringssammenhænge (f.eks. lærer-underviser-elev) eller mere uformelle (f.eks. storebror-hjælper-lillebror). Undersøgelsen af hvilke kulturelle narrativer, kommunikationen mellem lektiehjælper og elev faktisk knytter an til, og af hvilke roller, de giver hinanden i disse narrativer, vil derfor være indikator på, hvor formelt/uformelt rummet i praksis er. 
Positioneringsteori opererer med tre grundfænomener: Sproghandling, positionering og kulturelt narrativ ("cultural storyline" på engelsk). Disse bestemmer gensidigt hinanden i menneskelig interaktion. Gennem konkrete sproghandlinger knytter vi an til kulturelle narrativer og herigennem udpeger vi sociale positioner, forstået som dynamiske interaktionsroller, for os selv og dem, vi interagerer med - vi positionerer os selv og hinanden. Hvad vi har ret til at sige og gøre uden at træde ved siden af, afgøres af vores position og af det kulturelle narrativ, der er knyttet an til. Det er f.eks. typisk acceptabelt, at læreren afbryder en elev, der fremlægger løsning af en opgave, mens det typisk ikke er acceptabelt, at en elev gør det samme med læreren. Samtidig bestemmes den konkrete pragmatiske betydning af de enkelte sproghandlinger af vores positionering, ligesom denne også er med til at fastsætte, hvilke kulturelle narrativer sproghandlingerne knytter an til. Til eksempel: Sproghandlingen "Nu skal jeg vise dig, hvordan man gør" knytter an til et lærer-elev eller hjælper-hjælpende narrativ og positionerer den, der taler, som mere kompetent, handlekraftig og hjælpsom (lidt afhængigt af tonefaldet) i forhold til samtalepartneren. Er det på den anden side en elev, der siger sådan til en lærer, vil sproghandlingen have en anden betydning, givet samtalepartnernes vidensmæssigt asymmetriske sociale positioner: Den vil enten være en frækhed eller en tilkendegivelse af stort engagement $\mathrm{i}$ at vise læreren, at eleven kan løse den pågældende opgave, og den vil knytte an til tilsvarende kulturelle narrativer om hhv. den frække eller ivrige elev.

Greeno har udviklet denne grundlæggende positioneringsteori som analyseredskab til læringssammenhænge (Greeno, 2011), idet han fokuserer på læringspositionering, dvs. hvordan elever positioneres socialt og fagligt gennem klassens kommunikation om fagligt indhold. Hans analyser viser, hvordan samme situation kan byde på forskellige læringsmuligheder i praksis for forskellige elever (Greeno \& Gresalfi, 2008). Han skelner mellem systemisk og semantisk positionering, hvor førstnævnte angår relationen til de andre mennesker i situationen - hvem der har ret/pligt til at bidrage med hvad i læringskommunikationen - mens sidstnævnte angår tilgangen til det faglige indhold - om forståelse af begreber og metoder er centralt, eller om fokus er på at følge fastlagte faglige procedurer. Dette sidste kan illustreres med forskellen på i klasserummets læringskommunikation at arbejde med matematikopgaver som andengradsligninger med fokus på a) at formulere forståelse af de matematiske begreber og af hvorfor man kan anvende bestemte formler i løsningen af opgaverne eller b) blot at sætte tal ind i de pågældende formler og få et svar. Semantisk positionering angår således spørgsmålet, om eleverne (enkelte af dem eller dem alle sammen) positioneres til at involvere sig begrebsmæssigt eller blot proceduremæssigt med det faglige stof.

Systemisk positionering på sin side angår spørgsmålet om, hvem der igennem læringskommunikationens sproghandlinger positioneres med autoritet, troværdighed og kompetence i forhold til arbejdet med fagets indhold. I 
typiske klasserumssituationer er spørgsmålet mere konkret, om nogle eller alle elever positioneres som kompetente bidragydere f.eks. ved løsning af en opgave, eller om de positioneres som tilhørere/modtagere af forklaring fra læreren og/eller andre elever.

Greenos erklærede mål er "to contribute to the development of a theory of cognition and learning in interaction", hvor kognitiv psykologi og situeret (lærings-)kommunikationsanalyse integreres på en måde, der "involves considering information processing as an aspect of interaction in activity systems" (Greeno, 2011, pp. 41, 43). Afhængigt af ens kommunikations- og læringsteoretiske ståsted kan det synes nærliggende at kritisere ham for at tillægge den ene eller den anden side af disse to positioner for ringe betydning. Konkret: Enten klandre ham for ikke at tillægge individuel opbygning/tilegnelse af forståelse tilstrækkelig betydning (Bredo påpeger dette, jf. Bredo, 2011, og Vosniadou er en repræsentant for et sådant synspunkt, jf. ; Vosniadou, 2007). Eller påtale, at han overser, at hvad en given interaktion mellem mennesker handler om (hvad der er 'indholdet') altid først bestemmes gennem den konkrete interaktion, og at interaktionen på sin side ikke er determineret af f.eks. præeksisterende magtstrukturer. Og at det derfor er problematisk at skelne mellem semantisk og systemisk positionering, fordi det er $i$ interaktionen, at 'hvad' og 'hvem' afgøres - i ét med hinanden (Macbeth, 2011).

Det vil føre for vidt at diskutere sådanne indvendinger i detalje her; og vi må derfor nøjes med kort at kommentere følgende: Vi er enige i, at hvad der konkret tales om, bestemmes igennem den faktiske interaktion (sidste indvending), ligesom magtstrukturer forhandles i den konkrete situation. Men det ændrer ikke på, at der er kulturelle ressourcer (som de nævnte kulturelle narrativer), handlemåder, baggrundsforståelser og generelt praksislogikker, der rammesætter den måde, interaktionen foregår på, og er med til at sætte formål for og give betydning til det, der siges og gøres. I lektiehjælpssessionerne er det rammesættende for interaktionen, at skolen har en række fag, hvortil hører faglige begreber, procedurer, problemstillinger og paradigmatiske løsningsmåder, og at elever forventes at lære disse begreber, procedurer osv. At skelne mellem systemisk og semantisk positionering er en måde at tage højde for sådanne baggrundsmæssige rammesættende forhold på.

Hvad den første indvending angår, at Greenos tilgang negligerer individet og dets forståelsestilegnelse, kan man på den ene side sige, at det tværtimod netop er den enkelte elev, der er fokus på, givet at der i Lektier Online ydes entil-en lektiehjælp, og at vi undersøger de læringsmuligheder, kommunikationen i praksis byder på for eleven. Men at det på den anden side ganske rigtigt ikke er den faktiske tilegnelse af forståelse, vi ser på, men i stedet på de forudsætninger, der i kommunikationen etableres herfor. Det bør her bemærkes, at dette sidste udsagn er neutralt i forhold til, hvad der mere 
præcist er involveret i'forståelsestilegnelse', dvs. om dette f.eks. opfattes konstruktivistisk som opbygning af erkendeskemaer (Piaget, 1950; von Glasersfeld, 2001) eller sociokulturelt som appropriering af kulturelle handlemåder(Säljö, 2000; Wertsch, 1998). Vi henviser til Dohn (2016) for en udførlig diskussion af betydningen af positionering for individuel videnstilegnelse.

Tilsammen giver Greenos begrebsapparat fire typer læringspositioneringer (der selvfølgelig i praksis kan være realiseret i større eller mindre grad), nemlig

- systemisk-semantisk positionering som kompetent forståelsesmæssig bidragyder

- systemisk-semantisk positionering som kompetent procedurefølgebidragyder

- systemisk-semantisk positionering som modtager af forståelsesmæssig forklaring

- systemisk-semantisk positionering som procedurefølgemodtager

Med dette teoretiske afsæt var vores udvalgskriterier for nærmere analyse af sessioner mhp. undersøgelse af hypotesen og forskningsspørgsmål 2:

- Klare eksempler på de forskellige typer læringspositionering (hvis de forefindes) - i begge de primære kommunikationsmedier (tale og chat)

- I fald en klar linje tegner sig i, hvilke kulturelle narrativer der knyttes an til på tværs af de forskellige eksempler på læringspositionering: en afsøgning af potentielle modeksempler til anknytning til disse kulturelle narrativer

- Klare eksempler på, hvordan brug af medierne influerer på positioneringsprocessen

Formålet med det første udvalgskriterium var at se, om der tegnede sig klare linjer i, hvilke kulturelle narrativer der knyttes an til i kommunikationen mellem lektiehjælper og elev, og om disse kulturelle narrativer hidrørte et mere formelt eller mere uformelt læringsrum. Formålet med det andet udvalgskriterium var at se, om der i det optagne materiale var modeksempler på den identificerede linje. Det skal understreges, at vi naturligvis ikke i dette eksplorative studium, baseret på forholdsvis få optagelser, kan udelukke, at der kunne gives modeksempler i sessioner, vi ikke har optaget. Formålet med sidste udvalgskriterium var mere specifikt input til undersøgelsen af, hvordan de anvendte medier fungerer i læringskommunikationen. 


\section{Positioneringsanalyse}

I de optagne sessioner finder vi eksempler på alle typer af læringspositionering, og dette gør vi for begge primære kommunikationsmedier. De eksempler, vi finder på positionering af eleven som bidragyder i chat, er dog i de fleste tilfælde af procedurefølge- frem for af forståelsesmæssig art. Til sammenligning ser vi ved tale flere eksempler på forståelsesmæssig positionering. Af pladsmangel nøjes vi her med at gengive et illustrativt eksempel på hver af positioneringsmulighederne. I et par af eksemplerne er der også ansatser til andre læringspositioneringer.

Eksempel 1: Positionering som kompetent forståelsesmæssig bidragyder, tale

1. LH: Hvad skal du have hjælp til?

2. E: (fniser) Det er... Som sagt - det er kemi.

3. LH: Ja

4. E: Det er det her om...øh... [lægger billede af opgave på tavlen] isomemer.

5. LH: Iso... isomerer?

6. E: Isomerer, ja. Altså det er også det her... Det er opgave 145, jeg har brug for hjælp til.

7. LH: Ja (pause) Jeg slår lige op, så jeg ved, hvordan stofferne ser ud [slår op på Google. Begge tier stille]

8. LH: Hvad tror du om den første?

9. E: Æh... Altså der står jo "I hvilke af følgende tilfælde er der mulighed for geometriske isomerer". Isomerer. Og geometrisk det er jo meget det her med cis og trans.

10. [LH googler geometriske isomerer. LH er stille]

11. E: Forstår du

12. LH: Ja [tonefald lidt fraværende]

13. E: Så jeg tænker... den første der ... øhm..ja. jeg ved ikke sådan helt, hvordan jeg skal finde ud af om tilfældet

14. LH: Ved du hvad der kræves for, at der skal laves en cis-trans isomeri

15. E: Ja, det gør jeg [fast stemme]. øhm når det er cis, så står det ...er ...så er det på samme side. Altså $\mathrm{H}$ gru...hydrogen

16. LH: Ja...På samme side af hvad?

17. E: På samme side af dobbeltbindingen

18. LH: Ja... Er der en dobbeltbinding i det første stof?

19. E: Øh... Nej

20. LH. Nej. Så kan den have geometrisk isometri?

21. E: øhm... men jeg tænker... skal vi ikke tegne den?

22. LH: Det kan vi godt gøre. Lad os gøre det.

23. E: Fordi jeg tror det er på den måde min lærer vil gerne det at man tegner den og så kan man sige at den har ikke nogen dobbeltbinding og så kan man

24. LH Ja ok skal vi tegne den på tavle to?

25. E: Ja 
26. LH. Ja. Hvad skal vi starte med at tegne? Hvad er grunden i sådan et stof?

Igennem hele dette eksempel positioneres eleven af lektiehjælperen som kompetent bidragyder ved den stadige spørgen ind til, hvad eleven ved om emnet, og hvordan opgaven skal gribes an (linje 8, 14, 16, 18, 20, 26). Eleven accepterer denne positionering igennem sine svar og forhandler den også aktivt ved sin protest mod lektiehjælperens tilgang til løsning af opgaven i linje 21 og 23. Semantisk er der tale om en forståelsesmæssig positionering i både lektiehjælperspørgsmål og elevsvar, fordi der er fokus på elevens forståelse af de kemiske betegnelser. Denne forståelsesmæssige positionering kobles sekundært med positionering til procedurefølgen (linje 21, 24 og 26).

Eksempel 2: Positionering som kompetent procedurefølgebidragyder, chat

1. LH: Ved du hvordan vi løser integraler som den du viser her?

2. E: Skal man starte med at finde t?

3. LH: Ja vi laver integration ved substitution [sender] Vi finder først $t$ [sender, tjekker 'integration ved substitution' på et matematikwebsite].

4. E: er det $8 x+3$

5. LH: Det er et rigtig godt valg $\odot$ [sender] Kan du så skrive integralet op med $\mathrm{t}$

6. E: [skriver $\sqrt{ } \mathrm{tdx}$ på tavlen]. Skal jeg ikke også regne $\mathrm{dx}$ ?

7. LH: Jo det er det næste skridt [sender] Hvordan ændre vi dx til dt? [tilføjer integraltegn på elevens udtryk på tavlen]

8. E: Skal jeg først differentiere t?

Elev og lektiehjælper samarbejder her om en positionering af eleven som den, der skal foretage de nødvendige procedurer til at løse integralet, uden at det berøres, hvorfor integralet kan løses sådan. Derfor er der tale om en positionering til procedurefølgen. Lektiehjælperens tilføjelse af integraltegn i linje 7 er en sikring af, at det er det korrekte udtryk, som eleven regner videre på. Det er muligt, at lektiehjælperen tilføjer det uden kommentar, fordi det tager tid at skrive en chatbesked, og tilføjelsen under alle omstændigheder er synlig for eleven, der jo har mulighed for at spørge til det, hvis han/hun ikke forstår tilføjelsen. Uanset lektiehjælperens intention er resultatet en understregning i praksis af, at det er procedurefølgen, der er vigtigt, og derigennem af positioneringen af eleven til procedurefølgen.

Eksempel 3: Positionering som modtager afforståelsesmæssig forklaring, chat

1. E: $0 g M^{\prime}(60)$ det må give mere end 0

2. LH: Nej, uden at kende funktionen, så tror jeg at $\mathrm{M}^{\prime}(0)$ er et højere tal end $\mathrm{M}^{\prime}(60)$

3. E Nåå jo 
4. LH: Hvis du tænker på at stoffet begynder på sin omdannelse til $t=0$. Der vil det omdanne meget stof meget hurtigt [sender] Men som tiden går, så vil omdannelsen ske langsommere og langsommere [sender]

5. E: Vi starter jo med meget og så vil det blive reduceret

6. LH: Ja, men mængden af stoffet, det er stamfunktionen [sender] M(t) beskriver mængden af stoffet. [sender] $\mathrm{M}^{\prime}(\mathrm{t})$ beskriver hvor hurtigt det omdannes [sender] Kan du se forskellen? :) [søger på Google]

7. E: Jep

I dette eksempel positionerer lektiehjælperen eleven som modtager af forståelsesmæssig forklaring i linje 4 og 6 , og eleven accepterer denne positionering i linje 7. Det er interessant at bemærke, at eleven selv i linje 5 positionerer sig som bidragyder af forståelsesmæssig forklaring, som opfølgning på sin indikerede forståelse i linje 3. Elev og lektiehjælper "skriver lidt forbi hinanden" som følge af den længere kommunikationstid forbundet med chat: Det indikeres i chatruden, at den anden part skriver, men man kan ikke se hvad, før beskeden er sendt. Konkret skriver eleven linje 3, mens lektiehjælperen skriver første del af linje 4, og linje 5, mens lektiehjælperen skriver anden del af linje 4. Resultatet er en uenighed i praksis om positioneringen af eleven som bidragyder eller som modtager - en uenighed, der dog ikke adresseres og som opløses i elevens accept af forklaringen og af den positionering som modtager, som den indebærer.

Eksempel 4: Positionering som modtager af procedureforklaring, chat $i$ GoogleDoc

1. E: Jeg vil gerne have hjælp til databehandlingen. Jeg ved ikke rigtig hvad jeg skal lave der for at undersøge henfalsloven som er formålet med forsøget tror jeg

2. LH: Det er ok, lad mig lige læse færdigt (:) [læser opgaveordlyden, scroller mellem opgaveordlyden, nogle tabeller i opgaven og en tabel, eleven har lavet]

3. E: Ok $\odot$

4. LH: [scroller tilbage til der, hvor han skrev før, og fortsætter i samme afsnit] Jeg tænker du bare skal udfylde en tabel som vist under 5. Beregning, så kan du bruge den til at lave en regression.

5. E: Jeg har lavet regression men har ikke udfyldt tabellen for at lave det. sætter den lige ind 2 sek

6. LH: [scroller til opgavetabellen, mens eleven skriver] Alright, men du har altså lavet udregningerne som der bliver lavet i tabellen?

7. E: [indsætter billede af sin regressionstabel]

8. LH: [kigger på elevens regressionstabel, scroller mellem denne og opgavens tabel]

9. E: Nej har ikke lavet nogle udregninger har bare brugt tiden og differensen fx 5800-3400 og 8100-5800. Er det forkert? 
10. LH: Du skal umiddelbart beregne dN/dt-Ib hvor det er forskellen i antal divideret med forskellen i tid og fratrukket baggrundsstrålingen. Kan ikke rigtigt se om det er det du har gjort.

Denne chatsamtale finder sted i et GoogleDoc, hvor eleven har oploadet billeder af opgaveteksten, frem for direkte i Lektier Online-platformen. Der sker en klar positionering af eleven som modtager af procedureforklaring $\mathrm{i}$ linje 4, idet lektiehjælperen begynder at forklare eleven, hvad han/hun skal gøre, uden først at have spurgt, hvad det er, eleven ikke forstår, eller hvor langt han/hun selv er kommet med opgaven. Tilsvarende i linje 10, hvor lektiehjælperen fortæller eleven, hvad det er meningen, denne skal gøre, uden at spørge ind til elevens forklaring i linje 9 af udfyldningen af regressionstabellen, og uden at spørgsmålet om, hvorfor der skal regnes på den pågældende måde, adresseres.

Disse fire eksempler på læringspositionering illustrerer meget forskellige måder at gribe lektiehjælpen an på i praksis, ligesom de viser, hvordan elev og lektiehjælper forhandler lektiehjælpens form og dermed elevens positionering. I alle fire eksempler knyttes der an til et overordnet lærer-elev narrativ med lektiehjælperen i rollen som lærer. Elev og lektiehjælper er helt i overensstemmelse med hinanden i denne anknytning. Dette ses eksempelvis i det første uddrag, hvor lektiehjælperen indledningsvis knytter an til narrativet med spørgsmålet "hvad skal du have hjælp til", og hvor elevens reaktion (fnisen og afventning af lektiehjælperens googling) bekræfter lærerelev narrativet. Det overordnede narrativ realiseres dog forskelligt i eksemplerne: I de to første eksempler, hvor eleven positioneres som bidragyder, realiseres det som 'lærer-stimulerer-elev-til-at-artikulere-sig' i form af de tilskyndende spørgsmål, som lektiehjælperne stiller i hhv. linje 8, 14, 16, 18, 20, 26 (eksempel 1) og linje 1, 5 og 7 (eksempel 2). I eksempel 2 suppleres dette narrativ med 'den bekræftende lærer' i linje 3 og 7 og 'den rosende lærer' i linje 5. I de to sidste eksempler derimod, hvor eleven positioneres som modtager af forklaring, realiseres det overordnede lærerelev narrativ som 'lærer-forklarer-for-elev'.

Med konstateringen af dette gennemgående lærer-elev narrativ har vi undersøgt de optagne sessioner for modeksempler. Vi finder her faktisk eksempler på andre positioneringer. Imidlertid viser disse sig ved nærmere analyse stadig at holde sig inden for det overordnede narrativ, om end det forhandles lidt forskelligt af lektiehjælper og elev (sammen eller imod hinanden) i de enkelte tilfælde. Vi gengiver to eksempler til illustration her:

Eksempel 5: Lektiehjælper tilkendegiver sin tvivl, tale med kamera

1. LH: Nu skal jeg lige... Jeg slår lige op på Google medianen i en trekant, hvad det helt præcist er. Så vidt jeg ved er det vinkelhalveringslinjen... $ø \mathrm{hm} \ldots$

2. E: Jamen, det kan godt passe, for det var det også i den anden opgave 
3. LH: Ja. Så det er simpelthen, hvis vi har 34 grader her... [skriver på den trekant, eleven har tegnet på tavlen] så vil det sige, at der også er 34 grader hernede [peger med curseren]

4. E: Ja, det tror jeg.

5. LH: Yes

6. E: Men... nej nu skal jeg lige se noget... Der ligner det, at det stykke hernede [peger med curseren] den er meget mindre

7. LH: Ok?

8. E: Altså på den anden

9. LH: Kan du holde tegningen op foran kameraet evt.?

10. E: Ja, hvis du kan se... det er meget småt... Nu skal vi lige se...øhm... [holder bogen op; forsøger at finde en vinkel, så kameraet viser tegningen] Jeg ved ikke lige, hvordan det går det her

11. [De finder en vinkel gennem fælles kommunikation om, hvordan bogen skal holdes]

12. LH: Ja, det kan jeg godt se, den ser noget mindre ud. Så det vil sige, medianen ... [tjekker internetside] medianen det er... Det som medianen definerer, det er [skriver på tavlen mens han taler] en streg fra midtpunktet af den her side, $\mathrm{CB}$, det der det er midten af den her side ned til det hjørne her.

13. E: Så de er faktisk lige store de to stykker her?

14. LH: Lige præcis. Yes.

15. E: Ok.

16. LH. Så vi kan faktisk skrive hernede også [skriver på tavlen]. Den er også lig med 3,6.

17. E. Ja

18. LH: Ok. Em. Det der er med trigonometri er jo, at det arbejder rigtigt meget med retvinklede trekanter.

19. E: Mmmm.

20. LH: Så meget af det... mange af de trigonometriske funktioner kan vi ikke bruge medmindre en af vinklerne i trekanten er 90 grader.

Dialogen mellem lektiehjælper og elev er i starten mere symmetrisk, idet lektiehjælperen artikulerer sin usikkerhed med hensyn til, hvad en median er, og derigennem positionerer sig selv som en, der selv har læring behov. Umiddelbart kunne man derfor mene, at "den hjælpende storebror" var det kulturelle narrativ, der blev knyttet an til, eller endda "ligemænd, der samarbejder om en løsning". Elevens aktive bidrag, bl.a. med protest mod lektiehjælperens forklaring (linje 6), synes at understøtte denne tolkning. Som sådan kan eksemplet betragtes som et modeksempel til påstanden om en generel tilknytning til lærer-elev narrativet. Dette er imidlertid kun for en umiddelbar betragtning: Hele dialogen finder sted inden for en forståelse - fra både lektiehjælpers og elevs side - af, at det er lektiehjælperen, der skal levere forklaringen på, hvad en median er. Denne forståelse kommer til udtryk i elevens afventning af lektiehjælperens googling af begrebet, både i linje 3 og i 
linje 12, i lektiehjælperens forklarende udsagn i linje 3, 12, 16, 18 og 20, i elevens søgen bekræftelse i linje 13 og forståelsestilkendegivelse i linje 15, 17 og 19. I stedet for at være et modeksempel på lærer-elev narrativet, er eksemplet faktisk en yderligere bekræftelse af det. Det viser nemlig, at selv når lektiehjælperen i en konkret situation positioneres - af sig selv og af eleven - forholdsvis ligeværdigt med eleven fagligt set, sker denne umiddelbare symmetriske positionering stadig inden for en overordnet systemisk lærer-elev-ramme, hvor lektiehjælperen forventes at være den, der bringer begge ud af den faglige forvirring. Dvs. hvor lektiehjælperen semantisk positioneres med ansvarlighed, som den, der er kompetent bidragyder til den forståelsesmæssige afklaring.

\section{Eksempel 6: Lektiehjælper tager fejl, tale}

1. LH: Hvad er ...øh... grunden i det stof?

2. E: Jeg kan starte med at tegne hexan.

3. LH. Ja.

4. E: altså $6 \ldots 6$ carbonatomer.

5. LH: Aaa er der ikke ... [slår op på Google]

6. E: hex... jeg mener hexan det er 6.

7. LH: ja... det er 6. Det er helt rigtigt. Det er mig, der ikke kan huske de der græske tal.

8. E: Yes. Det har jeg også selv problemer med.

9. LH (griner svagt hørbart) [kigger på googleopslaget]

10. E: Men hvis jeg starter med at tegne 6

11. LH: Ja...

12. E: [tegner på tavlen] 2... 1, 2, 3... Ej! [sidste streg er blevet skæv]

13. LH: [kigger igen på tavlen] Jam... Prøv at tegne det med stregen, den anden øverste, så bliver det lige.

I dette eksempel begynder lektiehjælperen at rette på eleven (linje 5), men finder ud af, at hun tager fejl, og positionerer derefter eleven som den kompetente i forhold til det pågældende spørgsmål (linje 7). Hun positionerer sig selv som generelt (dvs. ikke kun hvad 'hexan' angår) ikke så kompetent mht. græske tal. Elevens svar i linje 8 'trøster' lektiehjælperen - men herigennem positionerer eleven sig som én, der niveau- eller statusmæssigt er stillet sådan i forhold til lektiehjælperen, at hendes faglige mangler kan trøste. Dvs. eleven positionerer sig som fagligt i hvert fald på lige fod med lektiehjælperen og snarere som fagligt hævet over denne. Eleven knytter herigennem an til et kulturelt narrativt som "den hjælpende storebror", men med sig selv, ikke lektiehjælperen, i rollen som storebroren. Dette er i udgangspunktet et modeksempel mod påstanden om et overordnet lærer-elev narrativ. Imidlertid peger lektiehjælperens reaktion (svag grinen) på, at hun finder elevens positionering af dem begge upassende. Dialogen fortsætter da også inden for et lærer-elev narrativ, hvor lektiehjælperen f.eks. i et lidt formelt tonefald i linje 13 fortæller eleven, hvordan hun skal tegne carbonatomernes placering. Selvom der kortvarigt er en mere symmetrisk 
forhandling af parternes respektive roller grundet lektiehjælperens fejltagelse og selv-positionering som følge heraf, peger eksemplet alt i alt ligesom Eksempel 5 på, at sådanne midlertidige forskydninger finder sted inden for det overordnede lærer-elev narrativ, som begge parter også hurtigt finder tilbage til igen efter forskydningen.

Vores analyse peger således på, at lektiehjælpen helt generelt finder sted rammesat af et kulturelt narrativ af formen lærer-underviser-elev, men at der er forskelle på, hvordan dette realiseres - typisk enten som lærer-stimulererelev-til-at-artikulere-sig eller lærer-forklarer-for-elev. Der kan kortvarigt forhandles mere symmetriske faglige positioner elev og lektiehjælper imellem, hvis lektiehjælperen tilkendegiver usikkerhed, men dette synes at finde sted inden for det overordnede lærer-elev narrativ, og parterne finder hurtigt tilbage til en direkte realisering af dette. Vores analyse indikerer derfor, at vi må afkræfte den hypotese, vi opstillede med afsæt i konceptet for Lektier Online. Det læringsrum, som det didaktiske design (betydning A) knyttet til Lektier Online frembyder, danner i praksis rammen for en lærer-elev kommunikation, og både lektiehjælper og elev positionerer sig selv og hinanden på måder, der understøtter denne kommunikation. Lektier Onlines læringsrum kan hævdes at bygge bro mellem skolens formelle læringskontekst og hjemmets uformelle lektielæsningskontekst, men det er ikke selv særligt uformelt, idet det grundlæggende trækker på undervisningsrummets sociale roller. Det er et forholdsvis trygt rum, hvor parterne er anonyme for hinanden, og hvor lektiehjælperen ikke har bedømmerroller over for eleven, som en lærer har. Men vejledningen kan alligevel ikke oplagt karakteriseres som en faglig støtte givet fra en mere erfaren peer grundet den stadige positionering fra både lektiehjælper og elev af lektiehjælperen i en lærerrolle.

\section{Medieanalyse}

I dette afsnit belyser vi det didaktiske design (betydning B) af Lektier Onlines platform og adresserer forskningsspørgsmål 1 og 2. Dette gøres med afsæt i begrebet 'affordances'. Dette begreb refererer til det interaktionspotentiale (altså potentiale for at interagere med og blive interageret med af), som omgivelserne byder på for en person, givet de erfaringer og kompetencer, som denne har. Med Gibsons klassiske eksempel: En vandret, udstrakt flade i knæhøjde (afhænger af personens størrelse) har affordancen 'at sidde på', givet bestemte kulturelle praksisser og udviklede kompetencer (nyfødte kan ikke sidde) (Gibson, 1986). Affordances er således ikke medierne hidrørende slet og ret, men er i stedet relative til den konkrete persons fysisk, personligt og kulturelt udviklede handlemuligheder (Dohn, 2009). Spørgsmålet om, hvilke affordances platformen har, er spørgsmålet om, hvilken brug de tilgængelige medier og deres integration i platformen gør naturlig for deltagerne, givet de kommunikationspraksisser de allerede har udviklet individuelt og kulturelt. Vi belyser dette spørgsmål gennem eksempler på hver 
af de fire kombinationer af primære kommunikations- og primære arbejdsmedier.

\section{Eksempel 1 fra tidligere - Tale med digital tavle}

Kommunikationsmediet muliggør - har affordance for - hurtige replikskift mellem samtalepartnerne. Dette udnyttes i eksemplet til at skabe en god dialog med deltagelse og interaktion fra begge parter. Arbejdsmediet gør det muligt at underbygge forståelsen ved at tegne, pege og sætte billeder ind, endda samtidig med at der tales. Eleven er den primære pennefører igennem opgaveløsningen, og dette er i sig selv med til at positionere eleven som bidragyder. En enkelt gang overtager lektiehjælperen pennen. Dette bevirker et midlertidigt skift fra positionering som forståelsesmæssig bidragyder til modtager af forståelsesmæssig forklaring, dels fordi det nu er lektiehjælperen, der er den aktive, dels fordi eleven ikke forstår lektiehjælperens tegning.

Eksempel 2 fra tidligere - Chat med digital tavle

Kommunikationsmediet chat har affordance for en langsommere dialog med længere svartid, hvor det kan være svært for lektiehjælperen at aflæse elevens tøven og vide, hvordan der skal handles på denne. Tøven kan f.eks. skyldes usikkerhed eller manglende faglig forståelse, men kan også skyldes, at eleven ikke er fuldt til stede. Igennem hele optagelsen svinger eleven mellem passiv og aktiv deltagelse i opgaveløsningen. Arbejdsmediet inddrages af begge parter til at tegne og underbygge forståelsen, endda samtidig som i linje 6-8, hvilket bidrager til positioneringen af begge som bidragydere.

Chattens affordance for tøvende og langsom responstid ses også i eksempel 4, hvor elev og lektiehjælper "skriver forbi hinanden". Endnu tydeligere er det i følgende eksempel:

\section{Eksempel 7 - Chat med digital tavle}

1. LH: Alright, skal vi tage den fra en ende af?

2. E: Ja

3. LH: Har du et forslag eller en ide til den første? [sender] Hvad er det for en substitution du skal lave? [sender]

4. [ Eleven skriver noget som ikke sendes]

5. LH: Substitution handler jo om at lave det til en integral vi kan finde ud af [sender] Så hvad skal vi gøre med den første til at gøre den overskuelig? [sender] Kan du integrere $\mathrm{x}^{\wedge} 5$ ? [sender]

6. E: Ja?

Denne dialog tager 2,5 minut. Eleven er lang tid om at svare, hvorfor lektiehjælperen vedbliver at sende yderligere procedurefølgebeskeder. Chattens affordance for langsom dialog og for sletning af beskeder uden at sende dem, elevens faktiske tøven og lektiehjælperens reaktion herpå bidrager derfor samlet til en positionering af eleven som modtager af procedureforklaring. 
I de tre eksempler med chat ser vi, hvordan chatfunktionen har affordance for at skabe usikkerhedsmomenter i kommunikationen, men at det er samspillet mellem elev, lektiehjælper og mediet, som i situationen afgør dialogens forløb.

\section{Eksempel 8 - Tale og Google Docs}

Lektiehjælpen angår korrekturlæsning på en dansk stil, hvor eleven allerede har skrevet stilen. Arbejdsmediet, Google Docs, har affordance for at gennemgå større tekstmængder og for, at begge parter kan deltage samtidigt og fuldt synligt for den anden, da ændringer i dokumentet vises, som de laves. Kommunikationen som tale bidrager til en god dialog, hvor begge er aktive samtidig med at der arbejdes kronologisk frem i Google Docs. Midtvejs i sessionen begynder eleven at arbejde hurtigere end lektiehjælperen. Fordi lektiehjælperen ud fra elevens markør kan se, hvor denne befinder sig i dokumentet, kan hun tilpasse sin vejledning af eleven til det, eleven arbejder på.

\section{Eksempel 4 fra tidligere - Chat i Google Docs}

Også her deles en større mængde tekst, nemlig opgaveordlyd og elevens udregninger. Havde arbejdsmediet været den digitale tavle, havde det været nødvendigt med flere tavler i brug. Dette ville besværliggøre arbejdet, fordi man ikke kan se, hvilken tavle den anden er på. I Google Docs er begge deltageres markører synlige i dokumentet. Google Docs kan endvidere anvendes til at chatte i, fortløbende med at opgaven løses. Det kan se uoverskueligt ud, når der chattes i forskellige afsnit og i forskellig kronologi, men når parterne formår at navigere i det - som her - bliver dialogen alt $\mathrm{i}$ alt mere struktureret end i chatfunktionen, hvor beskederne kommer efter hinanden i chatruden, uanset hvad de omhandler. Dialogen er også mere gennemsigtig end i chatfunktionen, fordi de hver især kan se, hvad den anden skriver, imens der skrives. Eksempelvis skriver lektiehjælperen linje 2, mens eleven er i gang med anden sætning af linje 1. At lektiehjælperen kan se det som eleven skriver, men sletter igen, giver flere muligheder for at opdage og handle på usikkerhed hos eleven. Dog kan man ikke både have overblik over dialogen og scrolle rundt i dokumentet samtidig. Dette bevirker en langsommere dialog.

I flere af eksemplerne (her repræsenteret ved uddrag 1, 2 og 4) anvender lektiehjælperen googlesøgninger og andre webmedier uden at inddrage eleven i disse. I eksempel 1 laver lektiehjælperen 8 forskellige googlesøgninger, som hun holder åbent i forskellige faner og bevæger sig ind og ud af mange gange undervejs i sessionen. I uddraget ses det, hvordan hendes googlesøgning påvirker kommunikationen forstyrrende (linje 10-13), fordi eleven misforstår hendes tavshed. Tavshed grundet googlesøgning virker ikke på samme måde forstyrrende i chat, men dette er i høj grad fordi lektiehjælper og elev, som ovenfor antydet, i det hele taget har meget mindre information om, hvad den anden foretager sig her. 
Giddens analyserer rum og tid som adskilte i den moderne verden (Giddens, 2003). Denne analyse må omfortolkes for Lektier Online. Her er de deltagende parter nødt til at være i det samme virtuelle rum og i den samme tid, for at kommunikationen lykkes. Der kan ikke tilføres kommunikation til rummet, når en af parterne er logget af som i andre virtuelle rum som blogs, GoogleDocs eller skype. Ydermere er de kun sammen på præcis denne platform og kan ikke se, hvad hinanden foretager sig i andre virtuelle eller fysiske rum. I enkelte optagelser kan man se på den interaktive tavle, at elevens curser bevæger sig op mod linjen med faner, som om eleven søger ind på et andet website, men lektiehjælperen kan ikke følge med i hvor.

Deltagerne er således på den ene side bundet til et fælles rum, men kan på den anden side "zappe" imellem forskellige rum og inddrage information fra andre medier uden at delagtiggøre den anden part heri.

Et lidt andet eksempel på dette haves i eksempel 5. Eleven vælger på et tidspunkt at regne opgaven færdig på papir uden for det fælles rum, mens lektiehjælperen venter. De taler derefter om, hvorvidt det fundne resultat er rimeligt, men lektiehjælperen ser ikke selve udregningen. Deres efterfølgende problemer med at løse resten af opgaven viser, at eleven må have lavet en bestemt fejl i disse udregninger, men dette bliver ikke klart for parterne, der ender med at måtte opgive opgaven. Det er selvfølgelig muligt, at fejlen heller ikke ville være blevet opdaget, selvom udregningerne havde været tilgængelige i det fælles rum, men under alle omstændigheder er det tydeligt, at muligheden for individuelt arbejdsrum uden for det fælles kommunikationsrum har den negative affordance at begrænse det, der kan kommunikeres forståeligt om, fordi det begrænser den fælles, tilgængelige information.

Generelt viser vores optagelser og observationer kun, hvordan lektiehjælperen bevæger sig omkring. Vi ser, at de en sjælden gang anvender lærebøger, men først og fremmest - og meget ofte - orienterer sig om begreber, formler og løsningsmetoder via googlesøgninger og/eller bestemte, faglige websites. Hvorvidt eleven også bevæger sig rundt og i hvilke medier, kan vi ikke se. Der er med andre ord ikke samme gennemsigtighed i, hvilke ressourcer lektiehjælper og elev hver for sig har til rådighed, og hvornår de benytter sig af dem, som der ville være i en læringskontekst, hvor både lektiehjælper og elev var fysisk til stede i samme lokale. Der synes heller ikke at være samme forventning om deling af viden - og om information om, at supplerende viden indhentes - som ved opgaveløsning i en fælles fysisk kontekst.

\section{Lektier Onlines implicitte didaktik - og kvalificering af den}

Positionerings- og medieanalyserne synliggør på den ene side en vejledningspraksis, der implicit er udtryk for nogle didaktiske principper for 
online lektiehjælp (didaktisk design i betydning D). På den anden side viser de eksempler på både hensigtsmæssig og uhensigtsmæssig kommunikation på Lektier Onlines platform i forhold til at understøtte elevernes læring. Fra disse eksempler kan trækkes en række implikationer i form af principper for, hvordan lektiehjælpen kan kvalificeres (didaktisk design i betydning C). I dette afsnit samler vi først op på den implicitte didaktik synliggjort gennem vores analyser for dernæst at adressere forskningsspørgsmål 3, dvs. hvilke didaktiske anbefalinger der følger af afvisningen af hypotesen samt redegørelsen for anvendelsen af Lektier Onlines medier i læringskommunikationen.

Vi har argumenteret for, at læringskommunikationen generelt knytter an til et lærer-elev narrativ, men at dette realiseres forskelligt i de fire basale læringspositioneringer. En grundskelnen er her den mellem systemisk positionering som kompetent bidragyder versus som modtager af forklaring, hvor den første eksempelvis etableres i sproghandlinger med narrativet lærer-stimulerer-elev-til-at-artikulere-sig, og den anden i sproghandlinger med narrativet lærer-forklarer-for-elev. Den første åbner muligheden for eleven at deltage i den faglige diskurs gennem anvendelse af fagets procedurer (ved procedurefølgen) og evt. metode- og begrebsudlægninger (forståelsesmæssigt bidrag). Den bygger derfor implicit på et didaktisk princip om læring gennem egen handling/aktiv involvering. Dette på sin side kan siges at bygge på mere konkrete (ikke sammenfaldende eller ækvivalente) didaktiske principper, f.eks. a) at man lærer gennem selv at artikulere sig, b) at man internaliserer begreber, metoder og procedurer gennem anvendelse af dem, c) at aktiv involvering indebærer konstruktion af erkendeskemaer eller d) at man gennem egen artikulation og de reaktioner, den afføder, indsocialiseres i den faglige diskurs. Positionering til modtager af forklaring vil i modsætning hertil ikke blot ikke åbne for mulighederne for at lære gennem egen aktiv deltagen, men reelt lukke for sådanne læringsmuligheder. I stedet åbner den muligheder for - og bygger på et didaktisk princip om læring gennem overføring og observation. Til grund for dette ligger ligeledes et eller flere mere konkrete (igen ikke sammenfaldende eller ækvivalente) didaktiske principper, f.eks. e) at en forklaret sammenhæng, systematik, eksemplificering osv. relativt direkte reproduceres i elevens forståelse, f) at elevens egen konstruktion af forståelse bedst støttes gennem observation af en anden, der gør det rigtigt, g) at observation af en rollemodels løsning af en opgave vil styrke elevens tro på, at han/hun selv ville kunne løse en lignende opgave en anden gang (Bandura, 1986), h) at socialisering ind i en faglig diskurs sker gennem observation af den.

Det skal understreges, at udpegningen af tilgrundliggende didaktiske principper er rent analytisk, med afsæt i den observerede læringskommunikation. Der ligger således ikke i udpegningen en accept af principperne eller bare en vurdering af, at de har en vis rimelighed. Rent faktisk stemmer flere af dem dårligt med læringsforskningen. Princip e) og f) 
problematiseres af både mere individualistisk konstruktivistiske retninger (von Glasersfeld, 2001; Vosniadou, 2007) og af sociokulturelt orienterede retninger (Greeno, 2011; Vygotsky, 1978), der med forskellige argumenter i stedet støtter a) og hhv. c) (konstruktivisme) og b) (sociokulturel teori). Selv kognitivistiske tilgange, der advokerer læring gennem instruktion, påpeger nødvendigheden af, at eleven engagerer sig kognitivt med materialet (Mayer, 2004). Sådanne tilgange kan derfor heller ikke uden videre acceptere e) og f). De vil omvendt godt kunne støtte kravet, som følger af a), om, at eleven selv skal artikulere sig fagligt, om end af andre grunde: Det er en måde at sikre, at eleven har forstået korrekt. Princip g) er kun effektivt, hvis rollemodellen er én, eleven mener, ligner ham/hende selv på relevant måde i forhold til løsning af opgaven, dvs. typisk en peer på nogenlunde samme niveau (Bandura, 1986; Schunk, 1987). Som positioneringsanalysen viser, er dette netop ikke tilfældet i Lektier Online. Hvad faglig socialisering angår, understøtter situeret klasserumsforskning d) på bekostning af h) (Greeno, 2011; Gresalfi, 2009). Alt i alt er der således læringsteoretisk belæg for en didaktisk praksis, der vægter læring gennem aktiv involvering, kognitivt og (i større eller mindre grad afhængigt af læringsteoretisk ståsted) i form af faglig handling som forståelsesartikulation og procedurefølgen.

Denne overordnede læringsteoretiske anbefaling koblet med vores analyser af den medierede læringskommunikation i Lektier Online, leder til en række mere konkrete anbefalinger til kvalificering af den måde, lektiehjælpen udøves på.

* Det er vigtigt for lektiehjælperen at være opmærksom på den læringspositionering, der sker i dialogen med eleven, og ikke mindst på den måde han/hun selv påvirker positioneringen på gennem konkrete sproghandlinger. En positionering af eleven som kompetent bidragyder er alt andet lige bedst. Den kan realiseres gennem spørgsmål til elevens forståelse og opgaveløsningsforslag og generelt gennem anerkendelse af elevens bidrag. Lykkes dette ikke (f.eks. fordi eleven ikke har forslag og/eller selv vedblivende positionerer sig som modtager af forklaring), er det vigtigt at understøtte elevens involvering med den forklaring, lektiehjælperen giver.

* I forlængelse heraf og givet, at læringskommunikationen medieres gennem Lektier Onlines platform:

- Eleven bør så vidt muligt være pennefører på den digitale tavle, idet dette i sig selv positionerer ham/hende som bidragyder. Hvis eleven ikke mener selv at kunne skrive/tegne det påkrævede, kan lektiehjælperen forsøge at guide eleven med ord. Dette vil visualisere elevens forståelse af lektiehjælperens forklaringer og dermed give mulighed for forståelseskontrol. Alternativt kan 
lektiehjælperen skrive/tegne og bede eleven redegøre for det skrevne/tegnede.

○ Kommunikationen bør holdes i det fælles rum eller i hvert fald føres tilbage ind i det fælles rum, så det er tydeligt for begge parter, hvilke begreber, udsagn og udregninger der kommunikeres om. Laver en af parterne 'mellemregninger' for sig selv uden for det fælles kommunikationsrum, skal disse gøres tilgængelig for den anden part bagefter.

* I det hele taget er det vigtigt at forholde sig til, hvilken information lektiehjælper og elev hver især har om, hvad den anden foretager sig - og at give den anden part nødvendig yderligere information for at imødekomme, at man ikke som ved fysisk tilstedeværelse umiddelbart kan se, hvor den anden har sit fokus.

○ Konkret bør lektiehjælperen informere eleven om det, når han/hun laver googlesøgninger eller besøger andre websites, så eleven ved, hvad en pause i kommunikationen fra lektiehjælperens side betyder.

* Gentagne bemærkninger til eleven om, at lektiehjælperen søger information til løsning af opgaven, vil positionere sidstnævnte med en mindre grad af autoritet. Dette kan være med til at mindske asymmetrien mellem lektiehjælper og elev og i sidste ende rokke ved tilknytningen til det overordnede lærer-elev-narrativ. Det bør under alle omstændigheder overvejes, hvor hensigtsmæssig dette narrativ er for elevens læringsmuligheder. Når læreren giver lektier for, er en grundpræmis et krav om selv-ansvar og om eget arbejde i eget tempo for at forstå og mestre fagets begreber og procedurer. Man kunne indvende, at en lektiehjælp, der grundlæggende finder sted inden for et lærer-elev narrativ, fjerner eller i hvert fald udvander dette krav.

* Endelig bør fokus på forståelsesudvikling versus procedurefølge overvejes ved hver session. Ideelt set bør hver lektiehjælpssession positionere eleven semantisk til forståelsesudvikling, men manglende elevforudsætninger og tidsrammen på 30-45 minutter kan umuliggøre dette. Det kan derfor være nødvendigt at nøjes med at hjælpe eleven til at mestre fagets procedurer.

\section{Konklusion}

I denne artikel har vi undersøgt det didaktiske design i Lektier Online, en lektiehjælpstilbud, der adskiller sig fra de fleste andre i offentligt regi ved at finde sted på en online platform, hvor elev og lektiehjælper er anonyme for hinanden. Artiklen er baseret på et empirisk studie af tilbuddets ungdomsuddannelsesdel, og vi har her set på det didaktiske design i fire 
betydninger af begrebet. Vi har gjort dette gennem undersøgelsen af en hypotese om Lektier Online-konceptet som frembydende et forholdsvis uformelt læringsrum samt tre eksplorative forskningsspørgsmål, der adresserer brugen af Lektier Online-platformens forskellige medier, deres virkemåde i læringskommunikationen mellem lektiehjælper og elev, samt muligheder for at kvalificere denne læringskommunikation didaktisk.

Konklusionen på vores undersøgelse er, at det didaktiske design (i betydning A, didaktisk organiseringsprincip) i Lektier Online frembyder et læringsrum, der af lektiehjælper og elev i samarbejde forhandles med anknytning til et lærer-elev narrativ, og som derfor ikke er synderligt uformelt. Vores undersøgelse af platformens didaktiske design (i betydning B, didaktisk tilrettelagt læringsmiljø) har peget på måder, hvorpå de primære kommunikationsmedier, tale og chat, understøtter dialogen og spiller sammen med de primære arbejdsmedier, digital tavle og GoogleDocs. Vi har her bl.a. påpeget, at tale har affordance for en hurtig dialog, og at det på sin side betyder, at kortvarige pauser (som ved googleopslag) kan forstyrre kommunikationen, hvis årsagen ikke er tydelig for den anden part. Chats langsommere tempo gør uforklarede pauser mindre påfaldende, men dette først og fremmest fordi der under alle omstændigheder er meget mindre information tilgængelig om, hvad den anden part foretager sig. Alle fire former for læringspositionering forefindes i begge kommunikationsmedier, men chats langsommere tempo har dog i højere grad affordance for procedurefølge end for forståelsesmæssig positionering. Hvad samarbejdsmedierne, den digitale tavle og GoogleDocs angår, har vi peget på betydningen af, at eleven er pennefører, idet dette i sig selv bevirker en positionering som bidragyder. Ligeledes har vi påpeget, at GoogleDocs understøtter en mere struktureret og gennemsigtig skriftlig dialog end chatfunktionen gør.

Hvad det didaktiske design i betydningen de implicitte didaktiske principper (betydning D) angår, har vi peget på, at den systemiske positionering som kompetent bidragyder bygger på et implicit didaktisk princip om læring gennem egen handling/aktiv involvering, mens positioneringen som modtager af forklaring bygger på læring gennem overføring og observation. Vi har argumenteret læringsteoretisk for det første didaktiske princip som det mest adækvate til planlægning og tilrettelæggelse af lektiehjælpen (didaktisk design i betydning 3). På baggrund af dette og af vores observationer af de anvendte mediers affordances og virkemåde i læringskommunikationen mellem lektiehjælper og elev, har vi til slut fremsat en række mere konkrete anbefalinger til, hvordan elevens positionering som bidragyder kan understøttes. Endelig har vi påpeget vigtigheden af at sikre gennemsigtighed i, hvad parterne hver især foretager sig uden for det fælles rum, og af at få evt. vidensinput og mellemregninger tilvejebragt i parternes individuelle arbejdsrum, tilbage ind i det fælles kommunikationsrum. 


\section{Referencer}

Bandura, A. (1986). Social foundations of thought and action: A social cognitive theory. Englewood Cliffs, NJ: Prentice Hall.

Bredo, E. (2011). The Interaction of Content and Control in Group Problem Solving and Learning. In T. Koschmann (Ed.), Theories of Learning and Studies of Instructional Practice (pp. 113-122). New York, NY: Springer.

Dohn, N. B. (2009). Affordances revisited: Articulating a Merleau-Pontian view. International Journal of Computer-Supported Collaborative Learning, 4(2), 151-170.

Dohn, N. B. (2016). Explaining the Significance of Participationist Approaches for Understanding Students' Knowledge Acquisition. Educational Psychologist, 1-22. doi: 10.1080/00461520.2016.1160321

Dohn, N. B., \& Hansen, J. J. (2016). Begrebet "didaktisk design" - et kritisk overblik over betydninger. In N. B. Dohn \& J. J. Hansen (Eds.), Didaktik, design og digitalisering (pp. 43-63). Frederiksberg: Samfundslitteratur.

Dohn, N. B., Hansen, J. J., Jensen, J., Johnsen, L., Lauridsen, E., Møller, M. H., \& Yepez-Reyes, V. (2016). Digital educational design - process, product, and practice. Paper presented at the Designs for Learning, 5th International Conference, København. http://www.designsforlearning2016.aau.dk/digitalAssets/198/19 8492_dfl_short-papers-final-2.pdf

Flyvbjerg, B. (2006). Five Misunderstandings About Case-Study Research. Qualitative Inquiry, 12(2), 219-245.

Gibson, J. J. (1986). The ecological approach to visual perception. Hillsdale: Lawrence Erlbaum Associates.

Giddens, A. (2003). Modernitet og selvidentitet: selvet og samfundet under sen-moderniteten. Kbh: Hans Reitzel.

Greeno, J. G. (2011). A Situative Perspective on Cognition and Learning in Interaction. In T. Koschmann (Ed.), Theories of Learning and Studies of Instructional Practice (Vol. 1, pp. 41-71): Springer New York.

Greeno, J. G., \& Gresalfi, M. S. (2008). Opportunities to learn in practice and identity. In P. A. Moss, D. C. Pullin, J. P. Gee, E. H. Haertel, \& L. J. Young (Eds.), Assessment, equity, and opportunity to learn (pp. 170199). New York: Cambridge University Press.

Gresalfi, M. S. (2009). Taking up opportunities to learn: Constructing dispositions in mathematics classrooms. The Journal of the learning sciences, 18(3), 327-369.

Hansen, J. J., \& Remvig, K. (2016). Online lektiehjælp - Udvikling af en vejledningsdidaktik med pædagogisk designforskning som metode. Læring \& Medier, 15, 1-31.

Harré, R., \& van Langenhove, L. (Eds.). (1999). Positioning Theory. Oxford: Blackwell.

Macbeth, D. (2011). A Commentary on Incommensurate Programs. In T. Koschmann (Ed.), Theories of Learning and Studies of Instructional Practice (pp. 73-103). New York, NY: Springer.

Mayer, R. E. (2004). Should there be a three-strikes rule against pure discovery learning? American psychologist, 59(1), 14-19. 
Piaget, J. (1950). The psychology of intelligence (5. impr.. ed.). London: Routledge \& Kegan Paul.

Schunk, D. H. (1987). Peer Models and Children's Behavioral Change. Review of Educational Research, 57(2), 149-174.

Säljö, R. (2000). Læring i praksis - et sociokulturelt perspektiv. København: Hans Reitzels Forlag.

von Glasersfeld, E. (2001). Radical constructivism and teaching. Prospects, $31(2), 161-173$.

Vosniadou, S. (2007). The cognitive-situative divide and the problem of conceptual change. Educational Psychologist, 42(1), 55-66.

Vygotsky, L. S. (1978). Mind in Society: The Development of Higher Psychological Processes. Harvard: Harvard University Press.

Wertsch, J. V. (1998). Mind as action. New York: Oxford University Press.

'Video om Lektier Online, tilgængelig på http://www.lektieronline.dk/ 